\title{
HYDROGEOCHEMICAL QUALITY OF GROUNDWATER IN PERUMAL LAKE, KURINJIPADI TALUK, CUDDALORE DISTRICT, TAMILNADU, INDIA
}

\author{
Dr. P.Subramanian ${ }^{1 *}$, R. Krishnasamy ${ }^{2}$, S. M. Sakthivel ${ }^{3} \&$ Dr. G. Vijayakumar ${ }^{4}$ \\ 1,2,3\&4 Department of Civil Engineering, Excel Engineering College, Komarapalayam., \\ Namakkal District, Tamilnadu - 637303. \\ *Corresponding Author email address: Email: geosubbu27@gmail.com
}

\begin{abstract}
A study was carried out to determine the groundwater quality in parts of Perumal Lake, Kurinjipadi Taluk, Cuddalore district, Tamilnadu. Totally, 12 groundwater samples were collected at different parts of study area and 16 water samples from surface reservoirs (Perumal lake) and analyzed for physicochemical parameters ( $p H$, EC, TDS, TH, $\mathrm{Na}, \mathrm{K}, \mathrm{Ca}, \mathrm{Mg}$ and $\mathrm{Cl}, \mathrm{SO}_{4}, \mathrm{HCO}_{3}{ }^{-}, \mathrm{NO}_{3}$ ) in order to understand the hydro geochemistry of the water. The results of analysis were interpreted with geology and geomorphology of the area and also by various geochemical diagrams such as Piper trilinear plot and USSL classification diagram. Suitability of this water for its utility was verified using Indian standards. The result indicates irrespective of the seasons that only one well is suitable for drinking purpose, with remaining suitable for domestic and irrigation purpose. Further, from the results, it is pointed out that most of the well water falls in $\mathrm{Na}-\mathrm{Cl}$ type indicating the influence of seawater in these wells which was confirmed by Piper plot. According to SAR (alkali hazard) and specific conductance (Salinity hazard) is plotted in USSL diagram, classification of water for irrigation purpose can be determined. Majority of groundwater samples fall in C3S1 zone indicating high salinity and low sodium hazard, satisfactory for plants having moderate salt tolerance on soils. In surface water most of the samples fall in C2S1 indicates medium salinity and low sodium hazard.
\end{abstract}

[Keywords: Geochemistry: Major ion chemistry: Hydro-geochemical facies: Irrigation: water quality. Introduction

Groundwater is a precious and the most widely distributed resource of the earth and unlike any other mineral resource, it gets its annual replenishment from the meteoritic precipitation. Groundwater is the largest source of fresh water on the planet excluding the polar icecaps and glaciers. The amount of groundwater within $800 \mathrm{~m}$ from the ground surface is over 30 times the amount in all fresh water lakes and reservoirs, and about 3,000 times the amount in stream channels, at any one time. At present nearly one fifth of all the water used in the world is obtained from groundwater resources. Ground water is used for agriculture, industries and domestic supply in most parts of the world as it is a replenish able resource and has inherent advantages over surface water. Agriculture is the greatest user of water accounting for $80 \%$ of all consumption. It takes, roughly speaking 1000 tons of water to grow one ton of grain and 2000 tons to grow one ton of rice. Animal husbandry and fisheries all required abundant water. Some $15 \%$ of world's cropland is irrigated. The present irrigated area in India is 60 million hectares of which about $40 \%$ is from groundwater there has been a tremendous increase in the demand for fresh water due to growth in population, advanced in practices and industrial usages. Rapid growth of urban areas has affected the groundwater quality, due to over exploitation of recourse and improper waste disposal. A person normally requires about 3 quarts $(3 \mathrm{~L})$ of portable water per day to maintain the essential fluids of the body. Hence, there is a tendency to think of groundwater as (being) the primary water source in arid regions and of the surface water in humid regions. Hence the production and management of groundwater quality is emerging as a great public concern in India and other

countries of the world. However, the quality of groundwater available in an area is important as the quantity of resources.

Groundwater quality studies are becoming more important in nowadays due to manmade activities like domestic, industrial and agricultural activities. In urban area, the groundwater contamination occurs mainly due to domestic and industrial activities such as disposal of sewage water, septic tanks and industrial wastes. Groundwater quality studies are not critical when alternative sources are available. However, in many parts of the world, alternative supplies sufficient for the whole population particularly in urban areas, are not available. This is true in many parts of India in particular in the Cuddalore District where, although the majority of the population of hut-dwellers have no option but to use shallow wells as their only source of water. The water has become a scarce commodity in the region with ephemeral rivers and vagaries in monsoon. The study area is one on such, so, it is essential to have an idea about the quality of the existing water resource, which will help in the insatiable usage is future. Hence, an attempt has been made to study the hydrogeochemistry of the water in Cuddalore District.

\section{Materials and Methods Study area}

Perumal Lake is situated in Kurinjipadi taluk of Cuddalore district, Tamilnadu. It is located at $24.9 \mathrm{~km}$ east of Neyveli and $16.7 \mathrm{~km}$ south of Cuddalore. The length of lake is $13.05 \mathrm{~km}$ and it's having total perimeter $31.31 \mathrm{~km}$. The total area of lake is 5.037 sq.km. The lake is located in between the geographical coordinates, latitude of 111010'-11 ${ }^{\circ} 76^{\prime}$ and longitude of $79^{\circ} 37^{\prime}-7^{\circ} 42^{\prime}$ (Fig 1). The recharge source of lake is from the Gadilam River and Walaja tank and it also get water from Neyveli aquifers. 
Fig. 1. Location Map of the study area

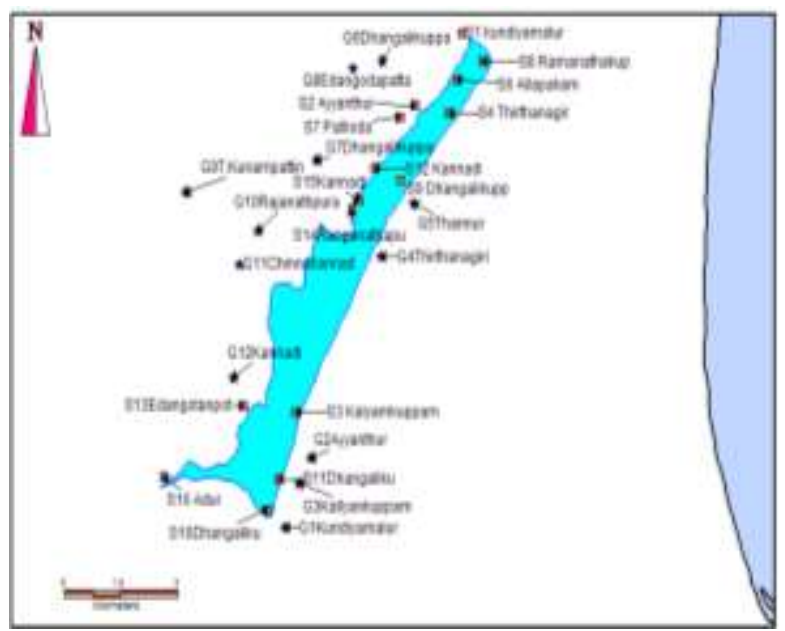

The Cuddalore district lies in the zone of tropical climate. The climate in the eastern part of the district is influenced by the adjoining Bay of Bengal. The India Meteorological Department (IMD) and the Groundwater Department of Public Works Department, Government of Tamil Nadu have established meteorological station at Cuddalore (N 110

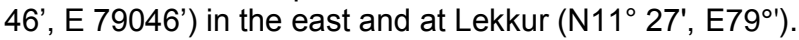

Sampling

A bore well may be taken as a sampling point for ground water and Perumal Lake for surface water. The quality of ground water is affected by the pumpage and natural discharge. The water is also heterogeneous in nature due to recharge from precipitation and contact with different types of rocks. Hence in the case of groundwater, the fixation of suitable sampling sites is not so easy as compared to surface water because the elements influencing water quality are not easily known. Some general suggestions can be made for the selection of sampling sites.

In case where the investigation does not take into account the changes in groundwater quality, the key constituents determined in a large number of samples collected over the entire area is utilized to determine the water quality of the study area. From this the sites for selection of samples for comprehensive analysis can be fixed. If the key constituents are not known at the beginning, the water quality pattern is arrived at, by first making a comprehensive analysis and thus partial analysis at other sites. 12 groundwater samples were collected at different parts of study area and 16 water samples from surface reservoirs (Perumal lake). One liter of water sample was collected in polyethylene bottle. The samples were than brought to the laboratory for analysis and stored properly $\left(4^{\circ} \mathrm{C}\right)$ before analysis.

\section{Results \& Discussion \\ Hydrochemistry of ground water}

In groundwater, $\mathrm{pH}$ varies from 6.13 to 8.46 with an average of 7.22 and in surface water it varies from 6.81 to 8.09 with an average of 7.26 . EC varies from 409.00 to $4490.00 \mu \mathrm{s} / \mathrm{cm}^{2}$ with an average of $1878.75 \mu \mathrm{s} / \mathrm{cm}^{2}$. In surface water, it varies from 268.00 to $859.00 \mu \mathrm{s} / \mathrm{cm}^{2}$ with an average of $549.13 \mu \mathrm{s} / \mathrm{cm}^{2}$. In groundwater, TDS ranges from 286 to $2790 \mathrm{mg} / \mathrm{l}$ with an average of $1164 \mathrm{mg} / \mathrm{l}$. In surface water it varies from $160 \mathrm{mg} / \mathrm{l}$ to $527 \mathrm{mg} / \mathrm{l}$ with an average of 340.63 $\mathrm{mg} / \mathrm{l}$ (Table.1).

In groundwater, Ca varies from 20.00 to $140.00 \mathrm{mg} / \mathrm{l}$ with an average of $63.67 \mathrm{mg} / \mathrm{l}$. In surface water, it varies from 16 to $44 \mathrm{mg} / \mathrm{l}$ with average of $29 \mathrm{mg} / \mathrm{l}$. In groundwater, Mg values ranges from 0.1 to $45.60 \mathrm{mg} / \mathrm{l}$ with an average of $18.20 \mathrm{mg} / \mathrm{l}$. in surface water, it varies from 0.1 to $26.40 \mathrm{mg} / \mathrm{l}$ with an average of $8.25 \mathrm{mg} / \mathrm{l}$. In groundwater, Na varies from 36.70 to $505.70 \mathrm{mg} / \mathrm{l}$ with an average of $159.55 \mathrm{mg} / \mathrm{l}$ and in surface water; it varies from 13.20 to $91.95 \mathrm{mg} / \mathrm{l}$ with an average of $46.21 \mathrm{mg} / \mathrm{l}$. In groundwater, $\mathrm{K}$ ranges from 5.80 to $92 \mathrm{mg} / \mathrm{l}$ with average of $23.48 \mathrm{mg} / \mathrm{l}$ and in surface water; it varies from 6.10 to $16.30 \mathrm{mg} / \mathrm{l}$ with an average of $7.99 \mathrm{mg} / \mathrm{l}$.

In groundwater, $\mathrm{HCO}_{3}$ ranges from 36.60 to $549.00 \mathrm{mg} / \mathrm{l}$ with an average of $200.28 \mathrm{mg} / \mathrm{l}$. In surface water, it varies from 73.20 to $170.80 \mathrm{mg} / \mathrm{l}$ with an average of $93.03 \mathrm{mg} / \mathrm{l}$. In groundwater, SO4 ranges from 0.68 to $248.33 \mathrm{mg} / \mathrm{l}$ with an average of $78.13 \mathrm{mg} / \mathrm{l}$. In surface water, it varies from 73.20 to $170.80 \mathrm{mg} / \mathrm{l}$ with an average of $93.03 \mathrm{mg} / \mathrm{l}$. In groundwater, $\mathrm{Cl}$ ranges from 88.62 to $478.58 \mathrm{mg} / \mathrm{l}$ with an average of $230.43 \mathrm{mg} / \mathrm{l}$. in surface water, it varies from 53.18 to $124.10 \mathrm{mg} / \mathrm{l}$ with an average of $76.44 \mathrm{mg} / \mathrm{l}$. Silica is the second most abundant element in the earth crust and essential component of almost all minerals. In groundwater, $\mathrm{H}_{4} \mathrm{SiO}_{4}$ varies from 14.14 to $198.07 \mathrm{mg} / \mathrm{l}$ with an average of $79.71 \mathrm{mg} / \mathrm{l}$ and in surface water it varies from 14.14 to $109.69 \mathrm{mg} / \mathrm{l}$ with an average of $44.20 \mathrm{mg} / \mathrm{l}$. In groundwater, PO4 varies from 0.14 to $5.13 \mathrm{mg} / \mathrm{l}$ with an average of $3.69 \mathrm{mg} / \mathrm{l}$ and in surface water it varies from 0.04 to $6.04 \mathrm{mg} / \mathrm{l}$ with an average of $1.92 \mathrm{mg} / \mathrm{l}$.

\section{Sodium percentage ( $\mathrm{Na} \%)$}

Sodium concentration is very important in classification of irrigation water because sodium by the process of Base Exchange replaces calcium in the soil which reduces the permeability of soil. The sodium percentage (Doneen, 1948 ) is calculated as. 
Table 1. Chemical Concentration of this sample collected in the study area. (All values in $\mathrm{mgl}^{-1}$ except EC\&pH)

\begin{tabular}{|c|c|c|c|c|c|c|c|c|c|c|c|c|c|}
\hline $\begin{array}{c}\text { S.N } \\
0\end{array}$ & $\begin{array}{l}\text { Гур } \\
\text { e }\end{array}$ & pH & Ec & $\mathrm{Ca}$ & Mg & $\mathrm{Na}$ & K & $\mathrm{Cl}$ & $\mathrm{HCO}_{3}$ & $\mathrm{SO}_{4}$ & $\mathrm{PO}_{4}$ & $\begin{array}{c}\mathrm{H}_{4} \mathrm{SiO} \\
4\end{array}$ & TDS \\
\hline G1 & \multirow{12}{*}{ 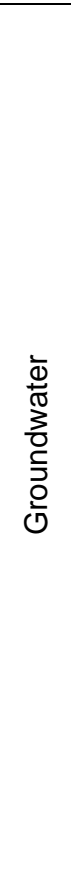 } & $\begin{array}{c}7.5 \\
4\end{array}$ & $\begin{array}{r}3640.0 \\
0\end{array}$ & $\begin{array}{r}140.0 \\
0 \\
\end{array}$ & $\begin{array}{r}45.6 \\
0 \\
\end{array}$ & $\begin{array}{r}275.8 \\
6 \\
\end{array}$ & $\begin{array}{r}34.7 \\
0 \\
\end{array}$ & $\begin{array}{r}460.8 \\
5 \\
\end{array}$ & $\begin{array}{r}219.6 \\
0 \\
\end{array}$ & $\begin{array}{r}248.3 \\
3 \\
\end{array}$ & $\begin{array}{r}5.0 \\
1 \\
\end{array}$ & 14.14 & $\begin{array}{r}2380.0 \\
0 \\
\end{array}$ \\
\hline G2 & & 7.1 & 2220.0 & & 14.4 & 269.3 & 21.1 & 354.5 & 183.0 & & 5.1 & & 1271.0 \\
\hline G3 & & $\begin{array}{r}1 \\
7.1 \\
6\end{array}$ & $\begin{array}{r}0 \\
3020.0\end{array}$ & $\begin{array}{r}52.00 \\
108.0\end{array}$ & $\begin{array}{r}0 \\
21.6\end{array}$ & $\begin{array}{r}0 \\
222.9\end{array}$ & $\begin{array}{r}0 \\
92.0\end{array}$ & $\begin{array}{r}0 \\
265.8 \\
7\end{array}$ & $\begin{array}{r}0 \\
329.4\end{array}$ & $\begin{array}{r}67.24 \\
216.1 \\
4\end{array}$ & $\begin{array}{r}3 \\
3.1 \\
1\end{array}$ & 109.70 & $\begin{array}{r}0 \\
1960.0 \\
0\end{array}$ \\
\hline G4 & & $\begin{array}{r}8.4 \\
6\end{array}$ & $\begin{array}{r}4490.0 \\
0\end{array}$ & 52.00 & $\begin{array}{r}33.6 \\
0\end{array}$ & $\begin{array}{r}505.7 \\
5\end{array}$ & $\begin{array}{r}50.5 \\
0\end{array}$ & $\begin{array}{r}178.5 \\
8\end{array}$ & $\begin{array}{r}549.0 \\
0\end{array}$ & $\begin{array}{r}4 \\
192.1 \\
2\end{array}$ & $\begin{array}{r}1.8 \\
5\end{array}$ & 95.21 & $\begin{array}{r}2790.0 \\
0\end{array}$ \\
\hline G5 & & $\begin{array}{r}7.1 \\
7 \\
\end{array}$ & $\begin{array}{r}2937.0 \\
0\end{array}$ & $\begin{array}{r}128.0 \\
0\end{array}$ & $\begin{array}{r}40.8 \\
0\end{array}$ & $\begin{array}{r}206.9 \\
0\end{array}$ & 8.20 & $\begin{array}{r}389.9 \\
5 \\
\end{array}$ & $\begin{array}{r}292.8 \\
0 \\
\end{array}$ & 72.05 & $\begin{array}{r}4.4 \\
6\end{array}$ & 198.07 & $\begin{array}{r}1660.0 \\
0\end{array}$ \\
\hline G6 & & $\begin{array}{r}6.1 \\
3 \\
\end{array}$ & 409.00 & 20.00 & 7.20 & 41.00 & 7.20 & 88.62 & 36.60 & 14.39 & $\begin{array}{r}4.2 \\
6 \\
\end{array}$ & 73.88 & 303.00 \\
\hline G7 & & $\begin{array}{r}6.3 \\
1 \\
\end{array}$ & 488.00 & 24.00 & $\begin{array}{r}12.0 \\
0 \\
\end{array}$ & 36.70 & 6.30 & $\begin{array}{r}106.3 \\
5 \\
\end{array}$ & 36.60 & 13.24 & $\begin{array}{r}4.9 \\
5 \\
\end{array}$ & 59.10 & 286.00 \\
\hline G8 & & $\begin{array}{r}7.1 \\
2 \\
\end{array}$ & 870.00 & 40.00 & $\begin{array}{r}14.4 \\
0\end{array}$ & 72.30 & 5.80 & $\begin{array}{r}141.8 \\
0\end{array}$ & $\begin{array}{r}158.6 \\
0 \\
\end{array}$ & 7.76 & $\begin{array}{r}4.9 \\
3\end{array}$ & 51.06 & 609.00 \\
\hline G9 & & $\begin{array}{r}7.0 \\
7 \\
\end{array}$ & 91.00 & 36.00 & 4.80 & 68.97 & $\begin{array}{r}12.3 \\
0 \\
\end{array}$ & $\begin{array}{r}106.3 \\
5 \\
\end{array}$ & $\begin{array}{r}158.6 \\
0 \\
\end{array}$ & 5.91 & $\begin{array}{r}5.0 \\
9 \\
\end{array}$ & 72.01 & 497.00 \\
\hline G10 & & $\begin{array}{r}7.3 \\
0\end{array}$ & $\begin{array}{r}1040.0 \\
0\end{array}$ & 40.00 & $\begin{array}{r}16.8 \\
0\end{array}$ & 76.90 & 8.20 & $\begin{array}{r}124.1 \\
0\end{array}$ & $\begin{array}{r}195.2 \\
0 \\
\end{array}$ & 0.68 & $\begin{array}{r}5.1 \\
3\end{array}$ & 53.55 & 627.00 \\
\hline G11 & & $\begin{array}{r}8.3 \\
3 \\
\end{array}$ & $\begin{array}{r}1130.0 \\
0 \\
\end{array}$ & 64.00 & 0.00 & 68.97 & $\begin{array}{r}11.6 \\
0 \\
\end{array}$ & $\begin{array}{r}124.1 \\
0 \\
\end{array}$ & $\begin{array}{r}158.6 \\
0 \\
\end{array}$ & 3.69 & $\begin{array}{r}0.1 \\
4 \\
\end{array}$ & 47.37 & 679.00 \\
\hline G12 & & $\begin{array}{r}6.9 \\
8\end{array}$ & $\begin{array}{r}1510.0 \\
0\end{array}$ & 0.00 & 7.20 & 68.97 & $\begin{array}{r}23.9 \\
0\end{array}$ & $\begin{array}{r}124.1 \\
0 \\
\end{array}$ & 85.40 & 96.06 & $\begin{array}{r}0.1 \\
7\end{array}$ & 61.53 & 12.00 \\
\hline S1 & \multirow{16}{*}{ 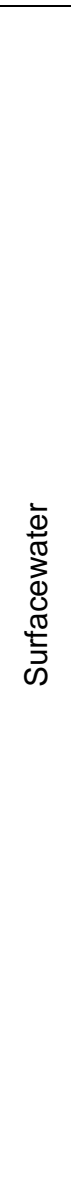 } & $\begin{array}{r}6.9 \\
5 \\
\end{array}$ & 4.00 & 28.00 & 9.60 & 50.57 & 7.10 & 70.90 & 85.40 & 48.03 & $\begin{array}{r}0.0 \\
4 \\
\end{array}$ & 42.33 & 357.00 \\
\hline S2 & & $\begin{array}{r}7.0 \\
1\end{array}$ & 4.00 & 0.00 & 0.00 & 0.46 & 8.30 & 70.90 & $\begin{array}{r}170.8 \\
0 \\
\end{array}$ & 5.27 & $\begin{array}{r}4.6 \\
0 \\
\end{array}$ & 47.49 & 416.00 \\
\hline S3 & & $\begin{array}{r}7.7 \\
4\end{array}$ & 736.00 & 44.00 & $\begin{array}{r}12.0 \\
0\end{array}$ & 43.90 & 7.50 & 70.90 & 85.40 & 73.60 & $\begin{array}{r}4.8 \\
2\end{array}$ & 46.62 & 433.00 \\
\hline S4 & & $\begin{array}{r}7.2 \\
9 \\
\end{array}$ & 44.00 & 0.00 & 0.00 & 1.95 & 6.10 & 88.63 & 85.40 & 48.03 & $\begin{array}{r}0.3 \\
6 \\
\end{array}$ & 41.61 & 390.00 \\
\hline S5 & & $\begin{array}{r}7.3 \\
7\end{array}$ & 32.00 & 8.00 & $\begin{array}{r}14.4 \\
0\end{array}$ & 7.47 & .50 & 88.63 & 3.20 & 9.61 & $\begin{array}{r}0.3 \\
3 \\
\end{array}$ & 50.91 & 423.00 \\
\hline S6 & & $\begin{array}{r}6.9 \\
8\end{array}$ & 6.00 & 2.00 & 7.20 & 7.47 & 7.10 & 88.63 & 5.40 & 3.42 & $\begin{array}{r}0.5 \\
0\end{array}$ & 49.50 & 416.00 \\
\hline S7 & & $\begin{array}{r}7.4 \\
0\end{array}$ & 1.00 & 32.00 & 7.20 & 7.47 & 7.00 & 88.63 & 5.40 & 35.01 & $\begin{array}{r}0.1 \\
0\end{array}$ & 39.18 & 370.00 \\
\hline S8 & & $\begin{array}{r}7.4 \\
3\end{array}$ & 15.00 & 32.00 & 2.40 & 7.47 & 7.40 & 70.90 & $\begin{array}{r}109.8 \\
0\end{array}$ & 9.61 & $\begin{array}{r}4.8 \\
4\end{array}$ & 37.66 & 431.00 \\
\hline S9 & & $\begin{array}{r}8.0 \\
9\end{array}$ & 05.00 & 28.00 & 9.60 & 22.99 & 8.00 & 70.90 & 97.60 & 3.56 & $\begin{array}{r}0.3 \\
5\end{array}$ & 17.02 & 240.00 \\
\hline $\mathrm{S} 10$ & & $\begin{array}{r}7.2 \\
9\end{array}$ & 6.00 & 28.00 & 4.80 & 34.48 & 6.70 & 70.90 & 97.60 & 3.83 & $\begin{array}{r}0.7 \\
5\end{array}$ & 25.34 & 257.00 \\
\hline S11 & & $\begin{array}{r}6.8 \\
1\end{array}$ & 8.00 & 20.00 & 9.60 & 22.99 & 6.40 & 53.18 & 85.40 & 48 & $\begin{array}{r}0.3 \\
3\end{array}$ & 51.50 & 160.00 \\
\hline S12 & & $\begin{array}{r}6.9 \\
6\end{array}$ & 282.00 & 30.00 & 2.40 & 18.39 & $\begin{array}{r}16.3 \\
0\end{array}$ & 53.18 & 85.40 & 4.26 & $\begin{array}{r}3.1 \\
2\end{array}$ & 46.38 & 172.00 \\
\hline $\mathrm{S} 13$ & & $\begin{array}{r}6.8 \\
1\end{array}$ & 268.00 & 20.00 & $\begin{array}{r}16.8 \\
0\end{array}$ & 16.09 & 6.80 & 70.90 & 85.40 & 4.62 & $\begin{array}{r}0.5 \\
3\end{array}$ & 14.14 & 161.00 \\
\hline S14 & & $\begin{array}{r}6.9 \\
5\end{array}$ & 274.00 & 16.00 & $\begin{array}{r}26.4 \\
0\end{array}$ & 13.20 & 7.50 & 53.18 & 85.40 & 19.21 & $\begin{array}{r}6.0 \\
4\end{array}$ & 109.69 & 192.00 \\
\hline S15 & & $\begin{array}{r}7.1 \\
4\end{array}$ & 722.00 & 36.00 & 2.40 & 68.97 & $\begin{array}{r}11.0 \\
0\end{array}$ & $\begin{array}{r}124.1 \\
0\end{array}$ & 85.40 & 4.10 & $\begin{array}{r}3.8 \\
2\end{array}$ & 51.98 & 505.00 \\
\hline S16 & & $\begin{array}{r}4.9 \\
1\end{array}$ & 859.00 & 40.00 & 7.20 & 45.50 & 7.10 & 88.63 & 85.40 & 19.21 & $\begin{array}{r}0.2 \\
0\end{array}$ & 35.81 & 527.00 \\
\hline
\end{tabular}

The concentrations of cations are in meq/l.

According to Wilcox (1995) classification, the water classified based on the Na\% with respect to the other cations present in water. $\mathrm{Na} \%$ for ground water study area 18 samples falls mostly in excellent quality 11 samples to good quality 
pre monsoon and post monsoon 12 samples falls excellent quality water and 18 samples to good quality of water remaining 2-3 samples observed in pre monsoon period falls permissible to doubtful and post monsoon period four samples falls in the permissible limit of quality water (Table 2).

Table 2. Comparison of chemical composition with WHO standard in $\mathrm{mg} / \mathrm{l}$

\begin{tabular}{|c|c|c|c|c|c|c|}
\hline \multirow{2}{*}{ Parameter } & WHO Standards 1977 & Groundwater & \multicolumn{2}{l|}{ Surfacewater } \\
\cline { 2 - 7 } & Highest value & Max. Permissible & Max. & Min. & Max. & Min. \\
\hline pH & $7.0-8.5$ & $6.5-9.2$ & 6.13 & 8.46 & 6.81 & 8.09 \\
\hline TDS & - & - & 286.00 & 2790.00 & 160.00 & 527.00 \\
\hline Calcium & 75 & 200 & 20.00 & 140.00 & 16.00 & 44.00 \\
\hline Magnesium & 30 & 150 & 0.00 & 49.60 & 0.00 & 26.40 \\
\hline Chlorine & 200 & 600 & 88.62 & 478.58 & 53.18 & 124.10 \\
\hline Sulphate & 200 & 400 & 0.68 & 248.33 & 3.56 & 89.61 \\
\hline Sodium & - & - & 36.70 & 505.75 & 13.20 & 91.95 \\
\hline Potassium & - & - & 5.80 & 92.00 & 6.10 & 16.30 \\
\hline
\end{tabular}

\section{Sodium Adsorption Radio (SAR)}

The SAR is useful for judging the quality of ground water for the use of agricultural purposes (Sastri and Lawrence, 1988). The Richard classified the waters in relation to irrigation based on the ranges of SAR values. According to Richards classification, all the samples of the study area have been classified as excellent for irrigation.

A more refined way of expressing the alkali hazard in irrigation water is shown by the U.S Salinity Laboratory (1954) diagram which takes into account the relative activity of sodium

in the exchange reaction in soil as expressed in terms known as SAR. The USSL diagram has been used to understand the alkali hazard of the groundwater samples of the study area, because this interpretation is very useful in judging the quality of groundwater for the use of agricultural purposes (Gurunadhan Rao et. Al., 2010). The USSL diagram prepared from the groundwater samples of the study area where the sodium adsorption ratio plotted against specific conductance. The sixteen classes in the diagram indicate the extent to which the waters can effect the soil in terms of salinity hazard as low (C1), medium(C2), high(C3) and very high (C4) and similarly sodium hazard as low (S1), medium (S2), high (S3) and very high(S4). The number of samples

$$
\text { SAR is defined by } S A R=\frac{\mathrm{Na}}{\sqrt{\mathrm{Ca}+\mathrm{Mg}) / 2}}
$$

\section{SAR concentrations of cations are in meq/l.}

\section{Residual Sodium Carbonate (RSC)}

Excess of $\mathrm{Mg}$ and $\mathrm{Ca}$ ions concentration trend to precipitate as carbonate. The sodium concentration increases and gets fixed in the soil thereby decreasing the soil permeability a high value of Residual sodium carbonate in water leads to an increase in the adsorption of sodium on soil. Irrigation of waters having Residual sodium carbonate values greater than 5 meql $^{-1}$ has been considered harmful to the growth of plants. RSC values between 2.5 meql ${ }^{-1}$ are generally considered unsuitable for irrigation purpose. The RSC value of between 1.25-2.5 meql ${ }^{-1}$ is marginal quality, while value of less than $1.25 \mathrm{meql}^{-1}$ indicates that water is safe. The RSC value of the water sample in the study area majority of samples in ground water and all samples fall in the fresh water category indicating water is fit for agriculture purpose. The irrigation water with high RSC is considered to be deleterious to the physical properties of the soil. The higher concentration of carbonate and bicarbonate ions is not suitable for irrigation.

USSL diagram, classification of water for irrigation purpose can be determined. Majority of groundwater samples fall in C3S1 zone indicating high salinity and low sodium hazard, satisfactory for plants having moderate salt tolerance on soils (Fig.2). In surface water most of the samples fall in C2S1 indicates medium salinity and low sodium hazard.

\section{Fig.2. USSL diagram, classification of Ground water}

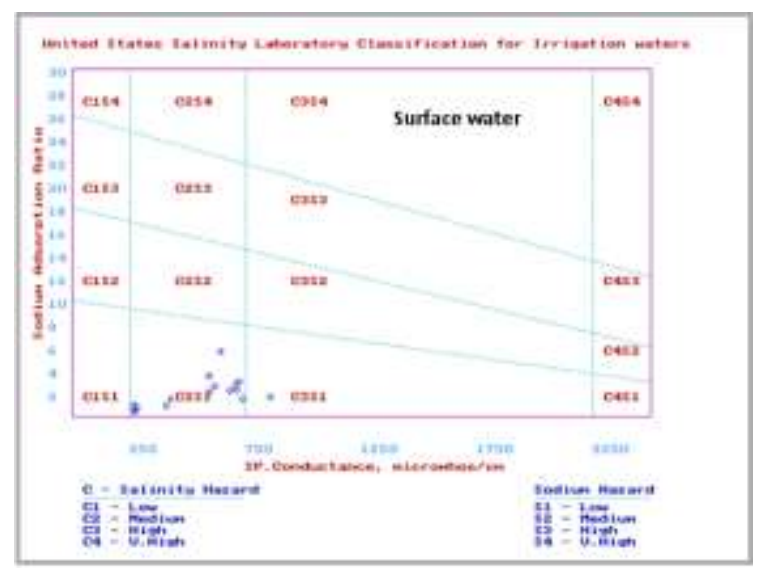

Permeability index is an important factor which influences quality of irrigation water, in relation to soil for development in agriculture. Based on permeability index, classified the groundwater as class I, class II and class III to find out suitability of groundwater for irrigation purpose (Fig.3). Most of the groundwater samples fall in class I indicating water is good for 
irrigation purpose with minor representation in class II. In surface water cluster of samples fall in class II indicating good to medium water for irrigation purpose.

\section{Fig.3. USSL diagram, classification of Surface water}

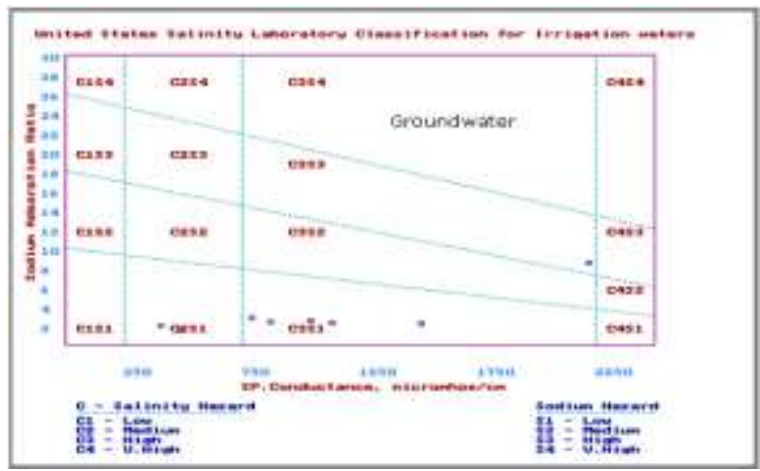

$\mathrm{Ca}-\mathrm{Na}$ and $\mathrm{Cl}-\mathrm{SO}_{4}-\mathrm{HCO}_{3}$ is the dominant facies in both surface and groundwater. Hardness of the water refers to the soap neutralizing power of water. Hardness refers to the reaction with soap and scale formation. It increases the boiling point and do not have adverse effect on health of human. Permanent hardness $(\mathrm{NCH})$ is higher in both surface and groundwater samples, when compared to the temporary hardness. In surface water most of the samples fall in slightly hard category and in groundwater, majority of samples fall in moderately hard category.

$\mathrm{Na}$ is an important cation which in excess deteriorates the soil structure and reduces crop yield (Ramappa \& Suresh, 2000). SAR values in all the major litho units ranges from excellent to good category. According to Wilcox classification (1955) the water is classified based on the Na\% with respect to the other cations present in water. Na\% for groundwater falls in permissible to doubtful region and surface water falls in good to permissible category. In Na \% classification of groundwater for irrigation purposes. Majority of samples in both surface and groundwater fall in safe zone

\section{Conclusions}

The increasing need for water, puts a high strain on the available water resource, automatically leads to the conservation of water and water resources. In regions of scanty rainfall, every drop of water has to be stored. The meteorological study point out the higher amount of rainfall is during the north east monsoon. The temperature of the region is higher in the summer. The study draws out the following conclusions;

1. The electrical conductivity of the study area shows that in groundwater it varies from $409 \mu \mathrm{s} / \mathrm{cm}$ to $4490 \mu \mathrm{s} / \mathrm{cm}$. But, surface water samples having EC less than $1000 \mu \mathrm{s} / \mathrm{cm}$.

2.Calcium is the dominant cation and bicarbonate is the dominant anion in the study area.

3.Based on hardness, the groundwater samples are moderately hard and surface water samples are slightly hard in nature.

4.Based on the water quality standards, all the ions are present within the permissible limits.

5.The quality of the groundwater is verified with WHO standards, which shows that almost all the samples are well within the suitable drinking purposes.

6. The groundwater nature is explained by the Piper Trilinear diagram, which indicates that the groundwater samples come under $\mathrm{Ca}-\mathrm{Mg}-\mathrm{Cl}$ and $\mathrm{Na}-\mathrm{Cl}$ types.

7.Geochemical processes of the study area is explained by Gibbs plot and identified rock water interaction, which is the major process controlling the groundwater chemistry of the study area.

8. The quality of the water for irrigation was estimated by USSL classification and $\mathrm{Na \%}$, indicates that all the samples range from good to permissible levels.

The conclusions derived indicate that the water is relatively free from pollution and anthropogenic influences except in few locations and the geochemical process dominantly controls the groundwater chemistry of the region.

\section{References}

1. Doneen LD (1948) The quality of irrigation water. California Agriculture Dept 4 - 11: 6 - 14.

2. Gurunadha Rao VVS, Dhar RL, Jayachand T, Khoker CS (2000) Groundwater contamination around Mathura Oil Refinery, Mathura Uttar Pradesh- An assessment through mass transport modelling. In: Proceedings of International seminar on applied hydro geochemistry, Annamalai University pp168 - 183.

3. Ramappa R and Suresh TS (2000) Quality of groundwater in relation to agricultural practices in Lokapavani river basin, Karnataka India. In: Proceedings of International seminar on applied hydro geochemistry, Annamalai University pp136 - 142

4. Razak M and Dazy J (1990) Hydrogeochemical characterization of groundwater mixing sedimentary and metamorphic reservoirs with combined use of piper's principle and factor analysis. J Hydrol 114: $371-393$.

5. Sastri JCV and Lawrence JF (1988) Hydrogeochemistry evaluation of Karaikudi Environs, Tamilnadu India. Geophysical Res Bull 26-1: $39-44$.

6. USSL (1954) Diagnosis and improvement of Saline and Alkali soils, USDA Handbook 60:147 Wetzel, R.G.,Limnology, Philadelphia, 1964.

7. WHO (1971) International standards for drinking water $3^{\text {rd }}$ edition Geneva, 70p

8. Wilcox LV (1955) Classification and use of irrigation water. U.S. Geological Department Agri Circ 969: 19p. 